\title{
ANTIMICROBIAL AND ANTHELMINTIC ACTIVITIES OF SOME NEWLY SYNTHESIZED TRIAZOLES
}

\author{
JEETENDRA KUMAR GUPTA ${ }^{1 *}$, PRADEEP MISHRA ${ }^{2}$ \\ ${ }^{1}$ Department of Pharmacology, Institute of Pharmaceutical Research, GLA University, Mathura - 281 406, Uttar Prasesh, India. \\ ${ }^{2}$ Department of Pharmaceutical Chemistry, Institute of Pharmaceutical Research, GLA University, Mathura - 281 406, Uttar Pradesh, India. \\ Email: jkgupta81@rediffmail.com \\ Received: 15 February 2017, Revised and Accepted: 11 March 2017
}

ABSTRACT

Objective: The objective of this work is to synthesize and evaluate some novel 1,2,4-triazoles.

Methods: Procedure includes synthesis of triazole compounds followed by biological evaluations. The synthesis was carried out in six steps with p-bromobenzoic acid as starting material and converting to ester and then to hydrazide. Hydrazide was then converted to 4-amino triazole. The amino triazole was then linked to different secondary amines using chloroacetyl chloride as the linking agent. All the synthesized compounds were characterized through Fourier transform infrared spectroscopy, gas chromatography-mass spectroscopy, and nuclear magnetic resonance. Further, the compounds were taken out for biological evaluations. To explore their effects, experiments were conducted on various micro- as well as macroorganisms. The toxicity profile was also tested in accordance with OECD 425 guideline on Wistar albino rats.

Results: The compounds were examined for antibacterial as well as antifungal activities. Among the all compound T71, T73, and T75 exhibited antibacterial activity, and compound T71 showed antifungal activity as well. The evaluation was also carried out for anthelmintic activities. The compounds were treated on Pheretima posthuma at various concentrations to explore their vermifuge and vermicidal action. The triazole linked with 1-methylpiperazine was found to have comparable activity to that of reference standards.

Conclusion: Triazoles are a most potent assemblage of fungal retardants. But depending on their substituents, they also have diverse pharmacological values. In this study, the compound T71 showed promising antimicrobial as well as anthelmintic action. Hence, it can be considered as a lead compound for further researches.

Keywords: Anthelmintic, Antimicrobial, Triazole, Piperazine, Albendazole.

(c) 2017 The Authors. Published by Innovare Academic Sciences Pvt Ltd. This is an open access article under the CC BY license (http://creativecommons. org/licenses/by/4. 0/) DOI: http://dx.doi.org/10.22159/ajpcr.2017.v10i6.17800

\section{INTRODUCTION}

Parasitic infections are the serious health crunch in the tropical regions including Asian continents. Helminths produce chronic illness, malnutrition, anemia, and immune-mediated inflammatory changes in human beings as well as in other animals [1]. There are many types of helminths out of which intestinal worms are most common. Intestinal worms are parasites that can infect gut lumen and may reach to the blood stream and other vital organs. There is a group of anti-helminthic drugs that expel parasitic worms from the body either by paralyzing or killing them without causing significant damage to the host. Hence, they may have vermifuge or vermicidal action [2]. Vermifuges are the drugs that cause expulsion of the worms from gut whereas vermicidals have a tendency to kill them [3]. World health organization recommends anti-helminthic medications such as benzimidazoles and praziquantel for medical care, even during pregnancy in the endemic regions, particularly where the prevalence and hygiene related risk factor is high [4]. On the basis of scientific literature we find that a majority of antiparasitic drugs are heterocyclic in nature [5]. They provide scaffolds on which pharmacophores can be arranged to obtain potent and desirable activity.

Chemistry of heterocyclic compounds constitutes one of the latitudinous and outstretched areas of biological system. They have great biochemical significance. Many natural, as well as synthetic drugs, are heterocyclic in nature. Naturally occurring heterocyclic compounds are extremely common as, for example, DNA, RNA, enzyme cofactors, plant pigments, hemoglobin, vitamins, and alkaloids [6]. The most common anthelmintic drug benzimidazole is also heterocyclic in nature. It consists of the fusion of benzene and imidazole. Many anthelmintic drugs as, for example, albendazole (ALB), mebendazole, and triclabendazole belong to the class benzimidazole [7].

In the past few decades, the influence of triazoles in different biological activities has grown up rapidly. It has become evident from the recent researches that the triazoles are not only antimicrobial or antifungal but also have many pharmacological activities [8]. Basic nucleus triazole, when fused to another heterocyclic ring, leads to widespread action and diverse biological applications such as antidepressant [9], anti-inflammatory [10], antitumor [11], and antiviral action [12]. Triazoles are distinguished class of heterocyclic compounds having broad spectrum biological properties. Hence, there has been substantial interest of researchers in the development of new triazole compounds. In view of this, an attempt has been made to explore pharmacological action of some newly synthesized triazoles.

\section{METHODS}

All the test compounds were synthesized by the method reported by us [1-4]. Chemicals and reagents utilized in the synthesis were procured from Sigma-Aldrich, Merck, and Spectrochem. The synthesis was carried out in six steps. The initial reactant compound was 4-bromobenzoic acid, which was converted into 4-ethanoylamino-3mercapto-5-(4-bromo) phenyl-1,2,4-triazole via six steps of synthesis (Figs. 1 and 2).

\section{Step 1: Synthesis of methyl ester [13]}

4-bromobenzoic acid $(0.1 \mathrm{~mol}, 20.1 \mathrm{~g})$ was taken in a round bottom flask with methanol $(100 \mathrm{~mL})$. Concentrated sulfuric acid (2 mL) 


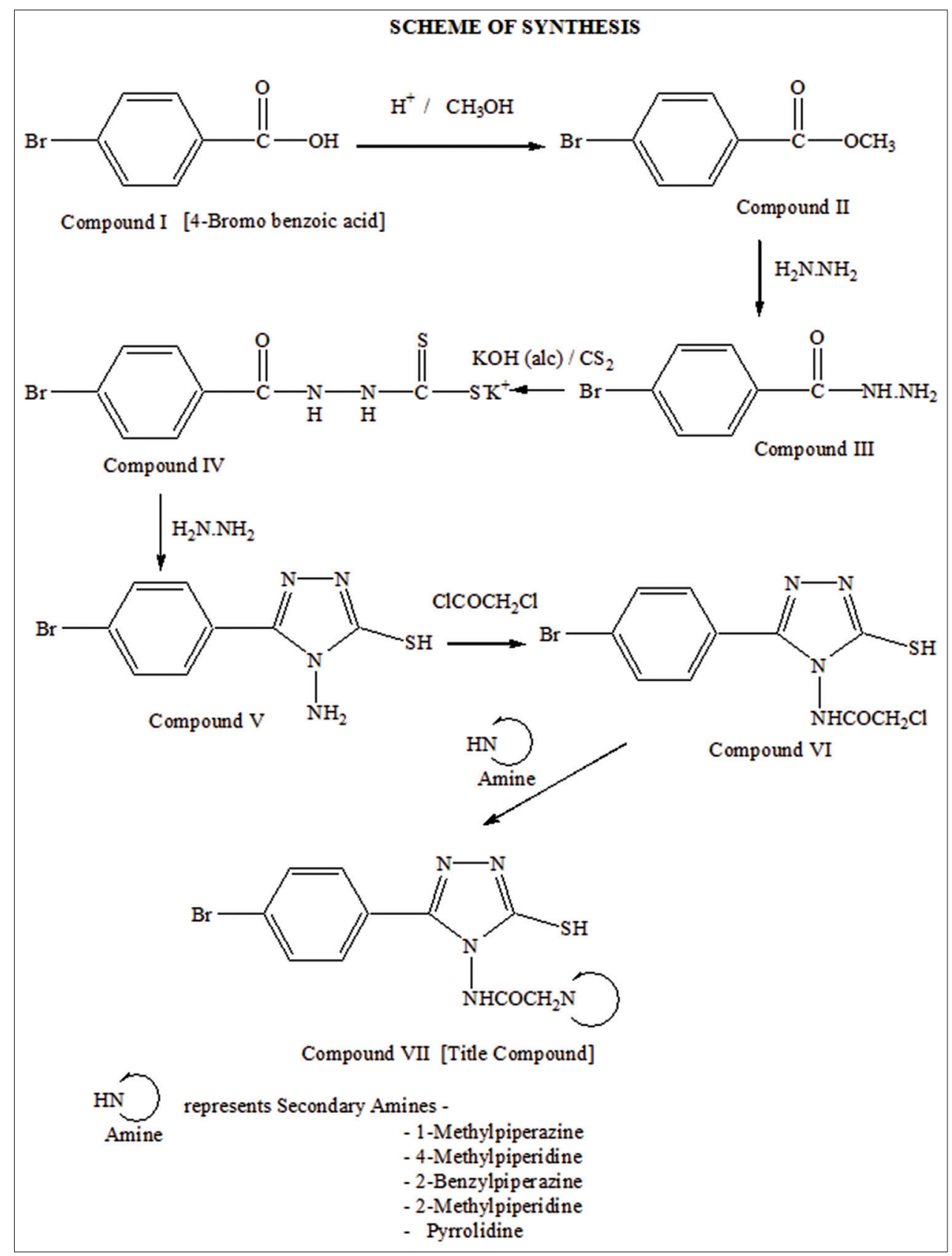

Fig. 1: Scheme of synthesis

was added to it. The reaction mixture was refluxed for $6 \mathrm{hrs}$. Excess of methanol was then distilled off at reduced pressure. The content was allowed to cool and transferred to separating funnel. The synthesized ester was extracted out using carbon tetrachloride. The mixed organic layer was washed with $5 \%$ solution of sodium bicarbonate to get rid of unreacted aromatic acid. The excess of carbon tetrachloride was then distilled off under reduced pressure to get pure ester, which was recrystallized using methanol. Yield: $19.5 \mathrm{~g}(91 \%), \mathrm{mp} 77-81^{\circ} \mathrm{C}$.

\section{Step 2: Synthesis of acid hydrazide [14]}

Acid hydrazide was synthesized by mixing methyl 4-bromobenzoate $(0.1 \mathrm{~mol}, 21.5 \mathrm{~g})$ with hydrazine hydrate $(0.15 \mathrm{~mol}, 5.7 \mathrm{~mL})$ in an alcoholic medium (methanol $100 \mathrm{~mL}$ ). The reaction mixture was refluxed for 4-6 hrs. Excess of alcohol was distilled off under reduced pressure. The obtained hydrazide was recrystallized using methanol. Yield: $20.2 \mathrm{~g}(94 \%), \mathrm{mp} 166-169^{\circ} \mathrm{C}$
Step 3: Synthesis of potassium 3-aroyl dithiocarbazate [15]

The synthesis of dithiocarbazate salt was carried out by reacting the hydrazide with alcoholic potassium hydroxide $(0.15 \mathrm{~mol}, 8.4 \mathrm{~g})$ along with carbon disulfide $(0.15 \mathrm{~mol}, 9 \mathrm{~mL})$. The alcoholic potassium hydroxide was prepared by mixing absolute ethanol $(75 \mathrm{~mL})$ with potassium hydroxide ( $8.4 \mathrm{~g}$ ). The reaction mixture was stirred for $16 \mathrm{hrs}$ at room temperature. The product was filtered off through Whatman paper and washed with dry ether to remove unreacted carbon disulfide. Further, the filtered salt was dried at room temperature and taken out for the next step.

Step 4: Synthesis of 4-amino-3-mercapto-5-phenyl-1,2,4-triazole [16,17] The thiocarbazate salt was refluxed with hydrazine hydrate $(0.2 \mathrm{~mol}, 7.6 \mathrm{~mL})$ and water $(6 \mathrm{~mL})$ in ethanol medium for 2-3 hrs. The color of reaction mixture changed to green, hydrogen sulfide gas evolved was tested by Lead acetate paper. The resultant homogeneous solution was allowed to cool and diluted with cold water $(100 \mathrm{~mL})$. The 


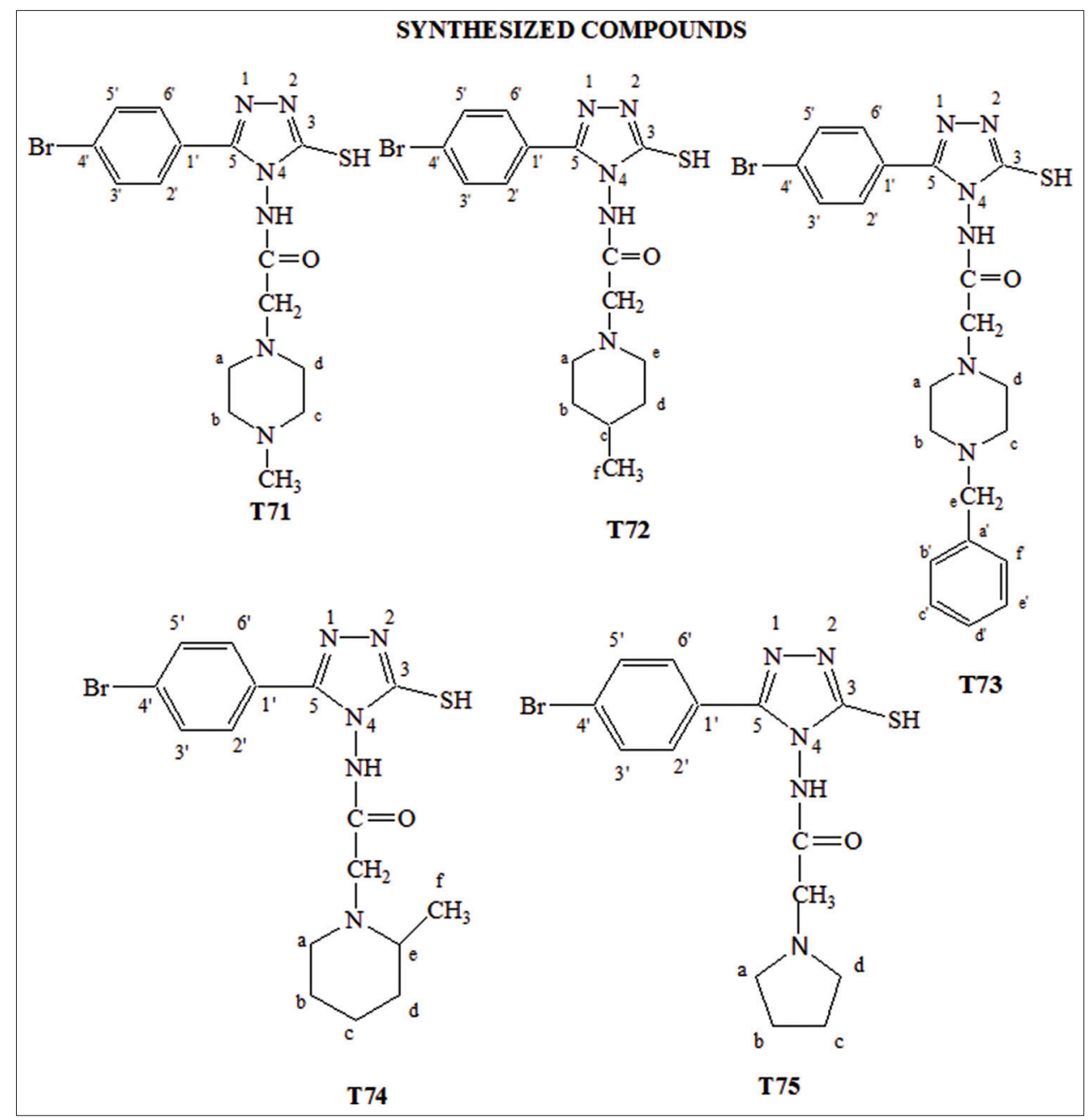

Fig. 2: Synthesized compounds

product was acidified with concentrated hydrochloric acid. A shifting of $\mathrm{pH}$ toward acid range resulted in heavy precipitation. The precipitated solid was filtered off and washed with distilled water. The product was recrystallized from equivolume ethanol-water mixture. Yield: $13.8 \mathrm{~g}$ (71.9\%), mp $205-207^{\circ} \mathrm{C}$.

Step 5: Synthesis of 4-chloroacyl amino-3-mercapto-5-phenyl1,2,4-triazole [18]

The synthesized triazole of the previous step was acetylated with chloroacetyl chloride $(0.11 \mathrm{~mol}, 8.75 \mathrm{ml})$ in dioxane medium. The reaction mixture was refluxed for $1 \mathrm{hr}$. The product was allowed to cool and poured on crushed ice. The precipitated product was filtered and repetitively washed with cold distilled water. Yield: $18.3 \mathrm{~g}(68 \%), \mathrm{mp} 182-184^{\circ} \mathrm{C}$.

Step 6: Synthesis of 4-(substituted ethanoyl)-3-mercapto-5phenyl-1,2,4-triazole [19]

The compound ( 0.025 mole) obtained from step " 5 " was solubilized in very little amount of dimethyl sulfoxide (DMSO) and then mixed with the respective amine ( 0.030 mole) along with the triethylamine $(0.030$ mole). The reaction mixture was taken in benzene $(75 \mathrm{~mL})$ and refluxed for $4 \mathrm{hrs}$. The precipitated triethylamine hydrochloride was separated out. Benzene was distilled off under reduced pressure. The product was further treated with ice cold distilled water, and the precipitated compound was filtered out using filter paper. Purification of the compound was done by repeated crystallization through appropriate solvent.

Melting points and percentage yield of the synthesized compounds were determined. The structures were elucidated by $\mathrm{CHN}$-analysis,
Fourier transform infrared (FTIR) spectroscopy, [13] C-nuclear magnetic resonance (NMR), ${ }^{1} \mathrm{H}-\mathrm{NMR}$, and gas chromatography-mass spectroscopy techniques. The physical and spectral data are arranged in Tables 1 and 2, respectively.

\section{BIOLOGICAL ACTIVITIES}

Screening tests (in-vitro) were carried out to explore the anthelmintic and antimicrobial activities of the synthesized compounds. Pheretima posthuma (in-vitro model) for anthelmintic activity and disc diffusion methods for antimicrobial activity were used accomplished with vehicle control and standard groups. The reference drugs as, for example, ALB, ciprofloxacin, and fluconazole were obtained from Cipla Limited, India. The P. posthuma (test organism for anthelmintic activity) was collected from the moist soil of the river bank of Yamuna. Micro-organisms for antimicrobial activity were obtained from Microbial Type Culture Collection (MTCC) Chandigarh. Other required ingredients and chemicals were procured from HiMedia, India.

\section{Anthelmintic activity}

The anthelmintic activity was carried out through in-vitro method [20-22] using P. posthuma. Since adult P. posthuma has anatomical and physiological resemblance with the intestinal roundworm parasites, the experiment was conducted on that test animal only. P. posthuma was placed in a petri dish containing test drugs at two different concentrations (10 and $20 \mathrm{mg} / \mathrm{mL})$. The time of paralysis was recorded when no locomotion of any sort was observed except when the worm was shaken vigorously. The time of death was 
Table 1: List of the synthesized compounds with nitrogen (\%) and $R_{f}$

Nitrogen \% found (calculated)

Solvent used for the determination of $\mathrm{R}_{\mathrm{f}}$ value - solvent system used: $\mathrm{n}$-hexane: ethyl acetate $(6: 4, \mathrm{v} / \mathrm{v})$

Table 2: Spectral data of synthesized compounds

\begin{tabular}{|c|c|c|c|c|}
\hline Compound & FTIR $\left(\mathrm{KBr}, \mathrm{cm}^{-1}\right)$ & ${ }^{1} \mathrm{H}-\mathrm{NMR}$ (DMSO-d6) $\delta \mathrm{ppm}$ & ${ }^{13} \mathrm{C}$-NMR (DMSO-d6) $\delta$ ppm & $\begin{array}{l}\text { GC-MS, } \\
\mathbf{m} / \mathbf{z}\left[\mathbf{M}^{+}\right]\end{array}$ \\
\hline $\mathrm{T}_{71}$ & $\begin{array}{l}3253 \text { (N-H), } 3095 \text { (C-H Ar.), } \\
2935 \text { (C-H Methyl), } 2594 \text { (S-H), } \\
1629(\mathrm{C}=\mathrm{O}), 1529 \text { (C=C), } \\
1497(\mathrm{C}=\mathrm{N}), 1486 \text { (C-H bend.), } \\
1172(\mathrm{C}-\mathrm{N})\end{array}$ & $\begin{array}{l}2.38\left(\mathrm{~s}, 3 \mathrm{H}, \mathrm{CH}_{3}\right), 2.58-2.62(\mathrm{~m}, 8 \mathrm{H}, \\
\left.\mathrm{CH}_{2} \text {-piperazine }\right), 3.40\left(\mathrm{~s}, 2 \mathrm{H}, \mathrm{COCH}_{2}\right), \\
\text { 7.77-7.79 (d, J=9.1, } 2 \times 1 \mathrm{H}, \mathrm{Ar}-\mathrm{H}), \\
\text { 8.14-8.16 (d, J=9.2, } 2 \times 1 \mathrm{H}, \mathrm{Ar}-\mathrm{H}) \\
9.87(\mathrm{~s}, 1 \mathrm{H}, \mathrm{CONH}), 13.96(\mathrm{~s}, 1 \mathrm{H}, \mathrm{SH})\end{array}$ & $\begin{array}{l}174.8\left(\mathrm{NHCO}^{\prime}\right), 167.0\left(\mathrm{C}_{5}\right), 148.4\left(\mathrm{C}_{3}\right), \\
131.3\left(\mathrm{C}_{3}^{\prime} \& \mathrm{C}_{5}^{\prime}\right), 129.8\left(\mathrm{C}_{2}^{\prime} \& \mathrm{C}_{6}^{\prime}\right), \\
124.9\left(\mathrm{C}_{1}^{\prime}\right), 124.1\left(\mathrm{C}_{4}^{\prime}\right), 59.4\left(\mathrm{COCH}_{2}\right), \\
54.8\left(\mathrm{C}_{\mathrm{b}} \& \mathrm{C}_{\mathrm{c}}\right), 53.1\left(\mathrm{C}_{\mathrm{a}} \& \mathrm{C}_{\mathrm{d}}\right), 45.0\left(\mathrm{C}_{\mathrm{e}}\right)\end{array}$ & 410 \\
\hline $\mathrm{T}_{72}$ & $\begin{array}{l}3320(\mathrm{~N}-\mathrm{H}), 3134 \text { (C-H Ar.), } \\
2974 \text { (C-H Methyl), } 2563 \text { (S-H), } \\
1618(\mathrm{C}=\mathrm{O}), 1506(\mathrm{C}=\mathrm{C}) \\
1486(\mathrm{C}=\mathrm{N}), 1477 \text { (C-H bend.), } \\
1240(\mathrm{C}-\mathrm{N})\end{array}$ & $\begin{array}{l}1.21\left(\mathrm{~s}, 3 \mathrm{H}, \mathrm{CH}_{3} \text {-piper. }\right) \\
1.84-1.98\left(\mathrm{~m}, 9 \mathrm{H}, \mathrm{CH}, \mathrm{CH}_{2}\right), 3.43(\mathrm{~s}, \\
\left.2 \mathrm{H}, \mathrm{COCH}_{2}\right), 7.85-7.88(\mathrm{~d}, J=9.2,2 \mathrm{H}, \\
\mathrm{Ar}-\mathrm{H}), 8.08-8.10(\mathrm{~d}, J=9.0,2 \mathrm{H}, \mathrm{Ar}-\mathrm{H}) \\
9.86(\mathrm{~s}, 1 \mathrm{H}, \mathrm{CONH}), 13.97(\mathrm{~s}, 1 \mathrm{H}, \mathrm{SH})\end{array}$ & $\begin{array}{l}175.4(\mathrm{NHCO}), 167.1\left(\mathrm{C}_{5}\right), 148.4(\mathrm{C} 3), \\
130.7\left(\mathrm{C}_{3}^{\prime} \& \mathrm{C}_{5}^{\prime}\right), 129.1\left(\mathrm{C}_{2}^{\prime} \& \mathrm{C}_{6}^{\prime}\right) \\
125.1\left(\mathrm{C}_{1}^{\prime}\right), 124.9\left(\mathrm{C}_{4}^{\prime}\right), 58.4\left(\mathrm{COCH}_{2}\right), \\
52.5\left(\mathrm{C}_{\mathrm{a}} \& \mathrm{C}_{\mathrm{e}}\right), 34.1\left(\mathrm{C}_{\mathrm{b}} \& \mathrm{C}_{\mathrm{d}}\right), 30.8\left(\mathrm{C}_{\mathrm{c}}\right) \\
22.8\left(\mathrm{C}_{\mathrm{f}}\right)\end{array}$ & 409 \\
\hline $\mathrm{T}_{73}$ & $\begin{array}{l}3312 \text { (N-H), } 3132 \text { (C-H Ar.), } \\
2958 \text { (C-H Methylene), } 2594 \text { (S-H), } \\
1628(\mathrm{C}=\mathrm{O}), 1532 \text { (C=C), } \\
1493(\mathrm{C}=\mathrm{N}), 1466 \text { (C-H bend.), } \\
1231(\mathrm{C}-\mathrm{N})\end{array}$ & $\begin{array}{l}\text { 2.44-2.48 (m, 8H, } \mathrm{CH}_{2} \text {-piperazine), } \\
3.40\left(\mathrm{~s}, 2 \mathrm{H}, \mathrm{COCH}_{2}\right), 3.75(\mathrm{~s}, 2 \mathrm{H}, \\
\left.\mathrm{CH}_{2}-\mathrm{Ar}\right), 7.49-7.49(\mathrm{~m}, 5 \mathrm{H}, \mathrm{Ar}-\mathrm{H}) \\
7.56-7.59(\mathrm{~d}, J=9.2,2 \mathrm{H}, \mathrm{Ar}-\mathrm{H}) \\
8.15-8.18(\mathrm{~d}, J=9.2,2 \mathrm{H}, \mathrm{Ar}-\mathrm{H}) \\
9.87(\mathrm{~s}, 1 \mathrm{H}, \mathrm{CONH}), 13.91(\mathrm{~s}, 1 \mathrm{H}, \mathrm{SH})\end{array}$ & $\begin{array}{l}174.8(\mathrm{NHCO}), 167.1\left(\mathrm{C}_{5}\right), 148.2\left(\mathrm{C}_{3}\right), \\
137.3\left(\mathrm{C}_{\mathrm{a}}^{\prime}\right), 135.4\left(\mathrm{C}_{3}^{\prime} \& \mathrm{C}_{5}^{\prime}\right), 129.9\left(\mathrm{C}_{\mathrm{b}}^{\prime}\right. \\
\left.\& \mathrm{C}_{\mathrm{f}}^{\prime}\right), 129.7\left(\mathrm{C}_{\mathrm{c}}^{\prime} \& \mathrm{C}_{\mathrm{e}}^{\prime}\right), 128.3\left(\mathrm{C}_{2}^{\prime} \&\right. \\
\left.\mathrm{C}_{6}^{\prime}\right), 127.0\left(\mathrm{C}_{\mathrm{d}}^{\prime}\right), 124.9\left(\mathrm{C}_{1}^{\prime}\right), 124.0\left(\mathrm{C}_{4}^{\prime}\right), \\
62.5\left(\mathrm{C}_{\mathrm{e}}\right), 58.7\left(\mathrm{COCH}_{2}\right), 52.7\left(\mathrm{C}_{\mathrm{a}} \& \mathrm{C}_{\mathrm{d}}\right), \\
52.5\left(\mathrm{C}_{\mathrm{b}} \& \mathrm{C}_{\mathrm{c}}\right)\end{array}$ & 486 \\
\hline $\mathrm{T}_{74}$ & $\begin{array}{l}3301(\mathrm{~N}-\mathrm{H}), 3104 \text { (C-H Ar.), } \\
2972 \text { (C-H Methyl), } 2557 \text { (S-H), } \\
1656(\mathrm{C}=\mathrm{O}), 1540(\mathrm{C}=\mathrm{C}) \\
1491(\mathrm{C}=\mathrm{N}), 1465 \text { (C-H bend.), } \\
1231(\mathrm{C}-\mathrm{N})\end{array}$ & $\begin{array}{l}1.19\left(\mathrm{~s}, 3 \mathrm{H}, \mathrm{CH}_{3}-\text { piper. }\right) \\
1.92-1.96\left(\mathrm{~m}, 9 \mathrm{H}, \mathrm{CH}, \mathrm{CH}_{2}\right), 3.39(\mathrm{~s}, \\
\left.2 \mathrm{H}, \mathrm{COCH}_{2}\right), 7.73-7.75(\mathrm{~d}, J=9.2,2 \mathrm{H}, \\
\mathrm{Ar}-\mathrm{H}), 8.13-8.15(\mathrm{~d}, J=9.2,2 \mathrm{H}, \mathrm{Ar}-\mathrm{H}) \\
9.86(\mathrm{~s}, 1 \mathrm{H}, \mathrm{CONH}), 13.95(\mathrm{~s}, 1 \mathrm{H}, \mathrm{SH})\end{array}$ & $\begin{array}{l}177.1(\mathrm{NHCO}), 167.1\left(\mathrm{C}_{5}\right), 148.3\left(\mathrm{C}_{3}\right), \\
131.2\left(\mathrm{C}_{3}^{\prime} \& \mathrm{C}_{5}^{\prime}\right), 129.9\left(\mathrm{C}_{2}^{\prime} \& \mathrm{C}_{6}^{\prime}\right) \\
124.9\left(\mathrm{C}_{1}^{\prime}\right), 124.2\left(\mathrm{C}_{4}^{\prime}\right), 58.8\left(\mathrm{COCH}_{2}\right), \\
56.4\left(\mathrm{C}_{\mathrm{e}}\right), 50.1\left(\mathrm{C}_{\mathrm{a}}\right), 34.5\left(\mathrm{C}_{\mathrm{d}}\right), 24.4\left(\mathrm{C}_{\mathrm{c}}\right), \\
24.1\left(\mathrm{C}_{\mathrm{b}}\right), 18.5\left(\mathrm{C}_{\mathrm{f}}\right)\end{array}$ & 409 \\
\hline $\mathrm{T}_{75}$ & $\begin{array}{l}3296 \text { (N-H), } 3125 \text { (C-H Ar.), } \\
2971 \text { (C-H Methylene), } 2591 \text { (S-H), } \\
1647 \text { (C=O), } 1546 \text { (C=C), } \\
1496(\mathrm{C}=\mathrm{N}), 1461 \text { (C-H bend.), } \\
1238(\mathrm{C}-\mathrm{N})\end{array}$ & 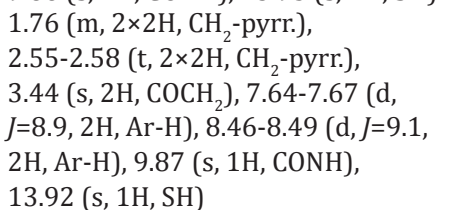 & $\begin{array}{l}176.0(\mathrm{NHCO}), 167.3\left(\mathrm{C}_{5}\right), 148.6\left(\mathrm{C}_{3}\right) \\
132.6\left(\mathrm{C}_{3}^{\prime} \& \mathrm{C}_{5}^{\prime}\right), 129.9\left(\mathrm{C}_{2}^{\prime} \& \mathrm{C}_{6}\right) \\
125.8\left(\mathrm{C}_{1}^{\prime}\right), 124.9\left(\mathrm{C}_{4}^{\prime}\right), 58.9\left(\mathrm{COCH}_{2}\right) \\
54.8\left(\mathrm{C}_{\mathrm{a}} \& \mathrm{C}_{\mathrm{d}}\right), 26.7\left(\mathrm{C}_{\mathrm{b}} \& \mathrm{C}_{\mathrm{c}}\right)\end{array}$ & 381 \\
\hline
\end{tabular}

DMSO: Dimethyl sulfoxide, FTIR: Fourier transform infrared, NMR: Nuclear magnetic resonance, GC-MS: Gas chromatography-mass spectroscopy

confirmed after ascertaining that worm neither moved when shaken nor when given external stimuli on any part of his body. The observation was carried out in triplet for mean paralysis time and death time.

\section{Antimicrobial evaluation}

The synthesized compounds were tested for antibacterial as well as antifungal activities. The antibacterial activity was carried out against Staphylococcus aureus (MTCC-3160), Bacillus subtilis (MTCC-10619),
Pseudomonas aeruginosa, (MTCC-424) and Escherichia coli (MTCC443). Antifungal activity was carried out using Aspergillus niger (MTCC9687), Candida albicans (MTCC-1637), and Fusarium oxysporum (MTCC-2087) fungal strains.

\section{Antibacterial activity}

Disc diffusion method [23-25] was performed in nutrient agar media. The agar media was inoculated with $0.1 \mathrm{~mL}$ (diluted in $0.4 \mathrm{~mL}$ of 
nutrient broth) of bacterial suspension containing 10 [8] cells $/ \mathrm{mL}$, equivalent to McFarland Nephelometer standard number 0.5. Whatman paper discs (diameter $5 \mathrm{~mm}$ ) were placed on the pre-inoculated agar media. Then, the discs were impregnated with a fixed volume $(30 \mu \mathrm{L})$ of compound dissolved in dimethylsulfoxide at different dilutions (6, 3 , and $1.5 \mathrm{mg} / \mathrm{mL}$ ). The plates were incubated at $35 \pm 1^{\circ} \mathrm{C}$ for $24 \mathrm{hrs}$. The compound less discs with DMSO were used as a control. Zone diameter was measured in millimeter. Further, the minimum inhibitory concentration (MIC) of the synthesized compounds was determined by broth dilution method $[26,27]$.

\section{Antifungal activity}

Similarly, the newly synthesized compounds were tested for antifungal activity. This activity was conducted using disc diffusion method [28-30]. Sabouraud dextrose agar media was used for C. albicans and A. niger, whereas potato sucrose agar was utilized as culture media against F. oxysporum. The tests were performed for all compounds at three dilutions. Zone of inhibition was measured in millimeter. To obtain MIC, the broth dilution method was followed [31].

\section{ACUTE ORAL TOXICITY (AOT) STUDY}

To explore the toxicity of the synthesized compounds, AOT studies were performed in accordance with OECD 425 guidelines [32]. An experiment conducted on Wistar albino rats. The test animals were critically observed for $24 \mathrm{hrs}$ and further for 14 days. The taken compounds did not produce any toxic effect even at $2000 \mathrm{mg} / \mathrm{kg}$ dose level (Fig. 3).

\section{RESULTS}

The compounds (T71-T75) were synthesized according to the scheme shown in Fig. 1. 4-bromobenzoic acid was converted into ester using methanol and concentrated sulfuric acid. In the next step, the ester treated with hydrazine hydrate and the hydrazide was synthesized. The hydrazide was cyclized into triazole with the help of alcoholic potassium hydroxide and carbon disulfide. The synthesized triazole (Compound V) treated with chloroacetyl chloride and in the past step, condensed with secondary amines to form the final compounds (T71-T75). All the synthesized compounds were characterized on the basis of FTIR, MASS, and NMR. In infrared spectroscopy, the final compounds exhibited C=N stretching band between 1486 and 1496/cm and C-N stretching band between 1072 and $1240 / \mathrm{cm}$, which signify the presence of 1,2,4-triazole ring. The series also showed absorption between 1618-1656/cm and $3253-3320 / \mathrm{cm}$, which is a typical feature of $\mathrm{C}=0$ stretching and $\mathrm{N}-\mathrm{H}$ stretching of the amide group. The presence of absorption band between 3095-3134/cm and 2557-2594/cm was a clear evidence for aromatic C-H stretching and $\mathrm{S}-\mathrm{H}$ stretching, respectively. In ${ }^{1} \mathrm{H}-\mathrm{NMR}$, the singlets of $\mathrm{CONH}$ and $\mathrm{SH}$ were observed in the range of $\delta$ 9.86$9.87 \mathrm{ppm}$ and $\delta 13.91-13.96 \mathrm{ppm}$, respectively. In [13] C-NMR spectra, C-5 and C-3 of the triazole nucleus were seen in the range of $\delta 167 \mathrm{ppm}$ and $\delta 148 \mathrm{ppm}$. Carbonyl and methylene carbon of $\mathrm{NHCOCH}_{2} \mathrm{~N}$ were observed at $\delta 174-177 \mathrm{ppm}$ and $\delta 58-59 \mathrm{ppm}$.

The compounds were evaluated for biological activities. Anthelmintic activity of the series has exhibited in terms of time of paralysis and time of death on P. posthuma. Compound T71 was found to be most effective vermifuge as well as vermicidal. It exhibited maximum potency with 24 minutes paralysis time and 37.33 minutes of death time at $20 \mathrm{mg} / \mathrm{mL}$ concentration. It showed significant activity at a dose $20 \mathrm{mg} / \mathrm{mL}$ (Table 3).

The compounds were also evaluated for antimicrobial activities using disc diffusion method at three concentrations. The zone of inhibition, as well as MIC, was observed. It was found that all the compounds possess antimicrobial activities. The compound T71 and T73 exhibited maximum potency of inhibition against the taken flora. They inhibit the growth of S. aureus and B. subtilis in notable way (Table 4-7).

The compound T73 showed antimicrobial activities against all the selected strains in a moderate manner whereas compound $\mathrm{T} 73$ showed

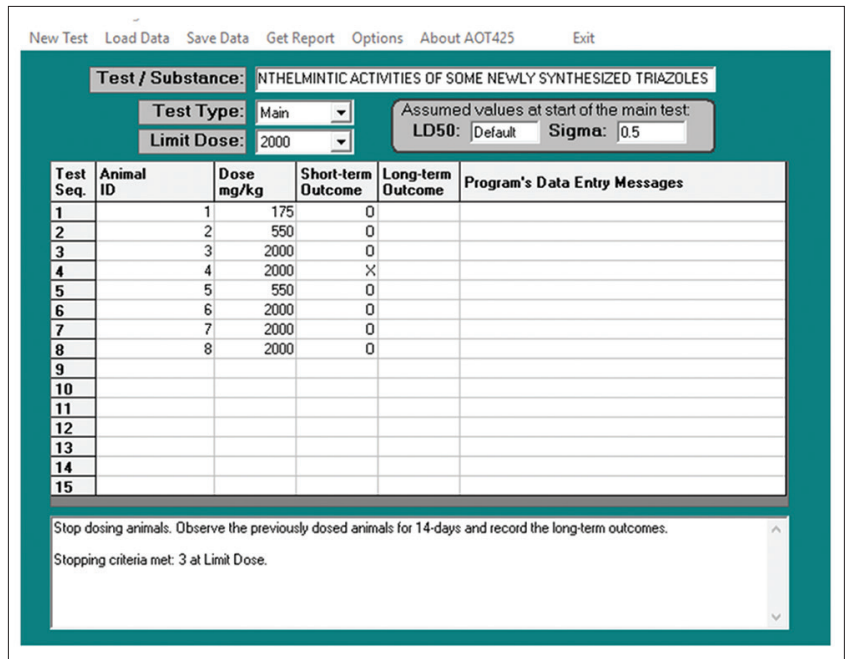

Fig. 3: Acute oral toxicity study (OECD 425 guideline)

Table 3: Anthelmintic activity of the synthesized compounds

\begin{tabular}{|c|c|c|c|c|}
\hline \multirow{3}{*}{$\begin{array}{l}\text { Test } \\
\text { compound }\end{array}$} & \multicolumn{4}{|c|}{ Time of paralysis and death } \\
\hline & \multicolumn{2}{|c|}{ Paralysis time (min) } & \multicolumn{2}{|c|}{ Death time (min) } \\
\hline & $10 \mathrm{mg} / \mathrm{mL}$ & $20 \mathrm{mg} / \mathrm{mL}$ & $10 \mathrm{mg} / \mathrm{mL}$ & $20 \mathrm{mg} / \mathrm{mL}$ \\
\hline Control & - & - & - & - \\
\hline $\mathrm{T} 71$ & $26.33 \pm 1.53$ & $23.00 \pm 1.00$ & $42.33 \pm 2.52$ & $37.33 \pm 2.08$ \\
\hline T72 & $52.33 \pm 1.53$ & $44.33 \pm 0.58$ & $60.33 \pm 2.52$ & $50.00 \pm 1.73$ \\
\hline T73 & $79.33 \pm 1.53$ & $72.33 \pm 2.52$ & $97.67 \pm 2.08$ & $89.00 \pm 3.61$ \\
\hline T74 & $80.33 \pm 2.52$ & $73.33 \pm 1.53$ & $96.33 \pm 1.53$ & $87.67 \pm 2.52$ \\
\hline T75 & $92.33 \pm 2.52$ & $87.33 \pm 2.52$ & $103.67 \pm 1.53$ & $92.67 \pm 2.52$ \\
\hline PZC & $31.33 \pm 1.53$ & $23.33 \pm 2.08$ & $89.33 \pm 0.58$ & $77.67 \pm 1.53$ \\
\hline ALB & $24.00 \pm 2.00$ & $17.33 \pm 2.52$ & $32.67 \pm 2.08$ & $26.33 \pm 0.58$ \\
\hline
\end{tabular}

All the values are in mean \pm SD ( $n=3$ ), SD: Standard deviation, PZC: Piperazine, ALB: Albendazole

a better effect against gram-positive bacteria. The significant result of antifungal activity was shown by T71, T73, and T75. Out of these, the inhibition produced by $\mathrm{T} 71$ was most promising.

\section{DISCUSSION}

Triazoles are an important class of heterocyclic compounds having diversified biological activities.

Triazoles available for accepted clinical use accommodate fluconazole, itraconazole, voriconazole and posaconazole. Although they all have similarity in their biological activities, but they have variable pharmacokinetics and physiological instability. Almost all are accepted for the prevention as well as treatment of invasive fungal infections. In this study, the amine linked triazoles were taken for dual evaluations. It is well-documented the fact that triazoles are known for their antifungal properties, whereas piperazine (PZC) citrate itself has very significant anthelmintic potential. Hence, the test compounds were taken for anthelmintic as well as for antimicrobial evaluations. The newly prepared compounds were screened for their acute toxicity in accordance with OECD 425 guideline. Subsequently, the compounds were also evaluated for anthelmintic, antifungal, and antibacterial properties. Appreciable effects were revealed by the compounds. The results were comparable with the reference drugs. The observation revealed that at the terminal position the compound with PZC group has greater potency as compared to the other compounds of the series. Thus, it can be said that compound T71 has not only antimicrobial activities but also anthelmintic action as well. SAR study of the synthesized compounds indicates that the secondary amine at terminal carbon has lead role and hence it can be considered as a pioneer work for future investigations. 
Table 4: Antibacterial activity of synthesized compounds (zone of inhibition)

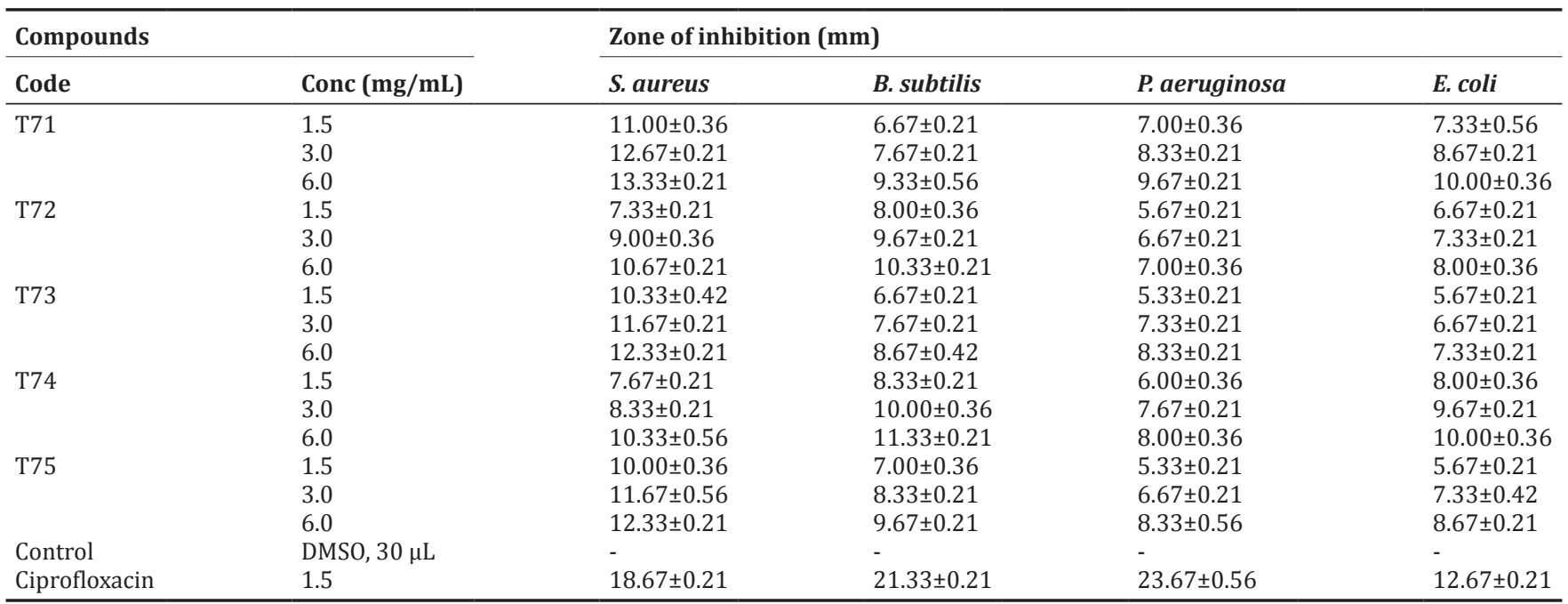

All the values are in mean \pm SEM (n=6). S. aureus (MTCC No: 3160), B. subtilis (MTCC No: 10619), E. coli (MTCC No: 443), P. aeruginosa (MTCC No: 424). DMSO: Dimethyl sulfoxide, SEM: Standard error of the mean, S. aureus: Staphylococcus aureus, B. subtilis: Bacillus subtilis, P. aeruginosa: Pseudomonas aeruginosa, E. coli: Escherichia coli, MTCC: Microbial Type Culture Collection

Table 5: MIC of synthesized compounds referring antibacterial activity

\begin{tabular}{lllll}
\hline Compounds & \multicolumn{2}{l}{ MIC, $\boldsymbol{\mu g} / \mathbf{m L}$} & & P. aeruginosa \\
\cline { 2 - 5 } & S. aureus & B. subtilis & 500 & 500 \\
\hline T71 & 125 & 500 & $>500$ & 500 \\
T72 & 500 & 250 & $>500$ & $>500$ \\
T73 & 125 & 500 & $>500$ & 500 \\
T74 & 500 & 250 & $>500$ & $>500$ \\
T75 & 125 & 500 & - & - \\
Control & - & - & 15.62 & 31.25 \\
Ciprofloxacin & 15.62 & 15.62 &
\end{tabular}

S. aureus (MTCC No: 3160), B. subtilis (MTCC No: 10619), E. coli (MTCC No: 443), P. aeruginosa (MTCC No: 424). S. aureus: Staphylococcus aureus,

B. subtilis: Bacillus subtilis, P. aeruginosa: Pseudomonas aeruginosa, E. coli: Escherichia coli, MIC: Minimal inhibitory concentration, MTCC: Microbial Type Culture Collection

Table 6: Antifungal activity of synthesized compounds (zone of inhibition)

\begin{tabular}{|c|c|c|c|c|}
\hline \multicolumn{2}{|l|}{ Compounds } & \multicolumn{3}{|c|}{ Zone of inhibition (mm) } \\
\hline Code & Concentration $(\mathrm{mg} / \mathrm{mL})$ & C. albicans & A. niger & F. oxysporum \\
\hline \multirow[t]{3}{*}{$\mathrm{T} 71$} & 1.5 & $18.67 \pm 0.21$ & $18.33 \pm 0.22$ & $13.33 \pm 0.21$ \\
\hline & 3.0 & $19.50 \pm 0.22$ & $19.17 \pm 0.17$ & $14.50 \pm 0.22$ \\
\hline & 6.0 & $20.50 \pm 0.22$ & $20.33 \pm 0.21$ & $15.33 \pm 0.21$ \\
\hline \multirow[t]{3}{*}{$\mathrm{T} 72$} & 1.5 & $9.33 \pm 0.21$ & $8.00 \pm 0.26$ & $7.17 \pm 0.31$ \\
\hline & 3.0 & $10.83 \pm 0.31$ & $9.67 \pm 0.21$ & $8.83 \pm 0.31$ \\
\hline & 6.0 & $11.67 \pm 0.21$ & $10.33 \pm 0.21$ & $9.33 \pm 0.21$ \\
\hline \multirow[t]{3}{*}{ T73 } & 1.5 & $14.67 \pm 0.33$ & $13.00 \pm 0.26$ & $11.50 \pm 0.22$ \\
\hline & 3.0 & $15.33 \pm 0.21$ & $14.67 \pm 0.21$ & $12.33 \pm 0.21$ \\
\hline & 6.0 & $16.67 \pm 0.21$ & $15.33 \pm 0.33$ & $13.67 \pm 0.21$ \\
\hline \multirow[t]{3}{*}{ T74 } & 1.5 & $7.50 \pm 0.22$ & $6.67 \pm 0.21$ & $7.33 \pm 0.21$ \\
\hline & 3.0 & $8.83 \pm 0.30$ & $7.83 \pm 0.17$ & $8.67 \pm 0.21$ \\
\hline & 6.0 & $10.00 \pm 0.36$ & $8.33 \pm 0.21$ & $10.00 \pm 0.25$ \\
\hline \multirow[t]{3}{*}{ T75 } & 1.5 & $6.83 \pm 0.30$ & $7.17 \pm 0.31$ & $8.67 \pm 0.33$ \\
\hline & 3.0 & $7.67 \pm 0.21$ & $8.00 \pm 0.26$ & $9.33 \pm 0.21$ \\
\hline & 6.0 & $8.67 \pm 0.21$ & $9.17 \pm 0.30$ & $11.00 \pm 0.26$ \\
\hline Control & DMSO, $30 \mu \mathrm{L}$ & - & - & - \\
\hline Fluconazole & 1.5 & $24.33 \pm 0.21$ & $23.33 \pm 0.42$ & $19.67 \pm 0.21$ \\
\hline
\end{tabular}

All the values are in mean \pm SEM ( $\mathrm{n}=6$ ). C. albicans (MTCC No: 1637), A. niger (MTCC No: 9687), F. oxysporum (MTCC No: 2087). SEM: Standard error of the mean, DMSO: Dimethyl sulfoxide, MIC: Minimal inhibitory concentration, C. albicans: Candida albicans, A. niger: Aspergillus niger, F. oxysporum: Fusarium oxysporum, MTCC: Microbial Type Culture Collection

\section{CONCLUSION}

It has been revealed that the triazoles linked with secondary amines have dose-dependent biological activities. In conclusion, this study reports on the anthelmintic as well as the antifungal potential of the triazole compounds. Compounds T71, T73, and T75 are active against C. albicans, A. niger and F. oxysporum, whereas compound T71 and T73 are active against $S$. aureus and $B$. subtilis. Anthelmintic potential was manifested in terms of paralysis time and death time of $P$. posthuma. 
Table 7: MIC of synthesized compounds referring antifungal activity

\begin{tabular}{llll}
\hline \multirow{2}{*}{ Compounds } & \multicolumn{2}{l}{ MIC, $\boldsymbol{\mu g} / \mathbf{m L}$} & \\
\cline { 2 - 4 } & C. albicans & A. niger & F oxysporum \\
\hline T71 & 31.25 & 31.25 & 125 \\
T72 & 250 & 250 & 250 \\
T73 & 125 & 125 & 125 \\
T74 & 250 & 500 & 250 \\
T75 & 500 & 250 & 250 \\
Control (DMSO 30 $\mu \mathrm{L})$ & - & - & - \\
Fluconazole & 7.81 & 7.81 & 15.61 \\
\hline
\end{tabular}

C. albicans (MTCC No: 1637), A. niger (MTCC No: 9687), F. oxysporum (MTCC No: 2087). MIC: Minimal inhibitory concentration, DMSO: Dimethyl sulfoxide C. albicans: Candida albicans, A. niger: Aspergillus niger, F. oxysporum: Fusarium oxysporum, MTCC: Microbial Type Culture Collection

The compound T71 was found to be more effective against the taken organism. Thus, in this study, we investigated the antimicrobial as well as antihelminthic activities of some newly synthesized triazoles.

In view of the above result and discussion, we conclude that the synthesized triazoles have a novel biological action against microorganisms as well as parasites. These results will serve as preliminary finding for further advance studies.

\section{ACKNOWLEDGMENT}

Authors are thankful to Institute of Pharmaceutical Research, GLA University Mathura, India, for providing research facilities for this work.

\section{REFERENCES}

1. Stepek G, Buttle DJ, Duce IR, Behnke JM. Human gastrointestinal nematode infections: Are new control methods required? Int J Exp Pathol 2006;87(5):325-41.

2. Deb PK, Ghosh R, Das S, Bhakta T. In-vitro anthelmintic activity of Acorus calamis leaves. Asian J Pharm Clin Res 2013;6:135-7.

3. Dahiya SS, Solanki, P. Evaluation of in vitro anthelmintic activity of methanolic extract of different parts of Spermacoce articularis. Int J Pharm Pharm Sci 2011;3:244-7.

4. Webb EL, Mawa PA, Ndibazza J, Kizito D, Namatovu A, Kyosiimire-Lugemwa $\mathrm{J}$, et al. Effect of single-dose anthelmintic treatment during pregnancy on an infant's response to immunisation and on susceptibility to infectious diseases in infancy: A randomised, double-blind, placebo-controlled trial. Lancet 2011;377(9759):52-62.

5. Darque A, Dumètre A, Hutter S, Casano G, Robin M, Pannecouque C, et al. Synthesis and biological evaluation of new heterocyclic quinolinones as anti-parasite and anti-HIV drug candidates. Bioorg Med Chem Lett 2009;19(20):5962-4.

6. Antus S, Gulácsi K, Juhász L, Kiss L, Kurtán T. Synthesis of naturally occurring o-heterocyclic compounds of biological activity. Pure Appl Chem 2004;76:1025-32.

7. Martin RJ. Modes of action of anthelmintic drugs. Vet J 1997;154:11-34.

8. Singhal N, Sharma PK, Dudhe R, Kumar N. Recent advancement of triazole derivatives and their biological significance. J Chem Pharm Res 2011;3:126-33.

9. Siddiqui N, Andalip, Bawa S, Ali R, Afzal O, Akhtar MJ, et al. Antidepressant potential of nitrogen-containing heterocyclic moieties: An updated review. J Pharm Bioallied Sci 2011;3(2):194-212.

10. Ahmadi F, Ghayahbashi MR, Sharifzadeh M, Alipoiur E, Ostad SN, Vosooghi M, et al. Synthesis and evaluation of anti-inflammatory and analgesic activities of new 1,2,4-triazole derivatives. Med Chem 2014:11(1):69-76.

11. Li X, Li XQ, Liu HM, Zhou XZ, Shao ZH. Synthesis and evaluation of antitumor activities of novel chiral 1,2,4-triazole Schiff bases bearing ?-butenolide moiety. Org Med Chem Lett 2012;2(1):26.

12. Somorai T, Szilágyi G, Reiter J, Pongó L, Láng T, Toldy L, et al. New acylated 1,2,4-triazoles as antiviral agents. Arch Pharm (Weinheim) 1986;319(3):238-42

13. Chernyshev VM, Chernysheva AV, Taranushich VA. Synthesis of esters and amides of 5-amino-1,2,4-triazole-3-carboxylic and 5-amino-1,2,4triazol-3-ylacetic acids. Russ J Appl Chem 2006;79:783-6.

14. Almasirad A, Mousavi Z, Tajik M, Assarzadeh MJ, Shafiee A. Synthesis, analgesic and anti-inflammatory activities of new methylimidazolyl-1,3,4-oxadiazoles and 1,2,4-triazoles. Daru 2014;22(1):22.

15. Upmanyu N, Gupta JK, Shah K, Mishra P. Anti-inflammatory and antinociceptive evaluation of newly synthesized 4-(substituted ethanoyl) amino-3-mercapto-5-(4-methoxy) phenyl-1,2,4-triazoles. J Pharm Bioallied Sci 2011;3(2):259-65.

16. Majumder S, Maya Bashyal B, Gupta RL. Synthesis of Schiff bases of 4-amino-3-mercapto-5-pyridin-4yl-4H-1,2,4-triazole and their evaluation as SAR inducers. Indian J Chem 2015;54:1260-74.

17. Upmanyu N, Kumar S, Shah K, Mishra P. Synthesis and antimicrobial studies of some 4-(Substituted)-ethanoylamino-3mercapto-5- (4-Substituted) phenyl-1,2,4-triazoles. Dhaka Univ J Pharm Sci 2012;11:7-18.

18. Upmanyu N, Kumar S, Porwal P, Shah K, Mishra P. Synthesis and evaluation of 4-(substituted)-acetylamino-3-mercapto-5-(4-substituted) phenyl-1,2,4-triazole derivatives as antimicrobial agents. Med Chem Res 2012;21:1967-76.

19. Upmanyu N, Gupta JK, Shah K, Mishra P. Synthesis of new 1,2,4-triazoles as anti-inflammatory and anti-nociceptive agents. Pharm Chem J 2011;45:433-9.

20. Mondal P, Jana S, Balaji A, Ramakrishna R, Kanthal L. Synthesis of some new isoxazoline derivatives of chalconised indoline 2-one as a potential analgesic, antibacterial and anthelmimtic agents. J Young Pharm 2012;4:38-41

21. Das SS, Dey M, Ghosh AK. Determination of anthelmintic activity of the leaf and bark extract of Tamarindus indica linn. Indian J Pharm Sci 2011;73:104-7.

22. Mohandas S, Sreekumar TR, Prakash V. Anthelmintic activity of Vidangadi Curna. Asian J Pharm Clin Res 2013;6:94-5.

23. Matar SA, Talib WH, Mustafa MS, Mubarak MS, AlDamen MA. Synthesis, characterization, and antimicrobial activity of Schiff bases derived from benzaldehydes and 3,3'-diaminodipropylamine. Arab J Chem 2015;8:850-7.

24. Paredes D, Ortiz C, Torres R. Synthesis, characterization, and evaluation of antibacterial effect of $\mathrm{Ag}$ nanoparticles against Escherichia coli O157:H7 and methicillin-resistant Staphylococcus aureus (MRSA). Int J Nanomed 2014;9:1717-29.

25. Hussain A, Zaman MK, Ramteke M. Antibacterial activity of trunk bark of Alstonia scholaris. Asian J Pharm Clin Res 2010;3:46-7.

26. Wiegand I, Hilpert K, Hancock RE. Agar and broth dilution methods to determine the minimal inhibitory concentration (MIC) of antimicrobial substances. Nat Protoc 2008;3:163-75.

27. Chandrappa SM, Gowda TS. Antibacterial activity of Coleus aromaticus leaves. Int J Pharm Pharm Sci 2010;2:63-6.

28. Shakhatreh MA, Al-Smadi ML, Khabour OF, Shuaibu FA, Hussein EI, Alzoubi KH. Study of the antibacterial and antifungal activities of synthetic benzyl bromides, ketones, and corresponding chalcone derivatives. Drug Des Devel Ther 2016;10:3653-60.

29. Bhalodia NR, Shukla VJ. Antibacterial and antifungal activities from leaf extracts of Cassia fistula 1.: An ethnomedicinal plant. J Adv Pharm Technol Res 2011;2:104-9.

30. Khor ES, Wong KV. Comparison study of therapeutic properties of proteins and secondary metabolites from Carica papaya. Int J Pharm Pharm Sci 2016;8:153-8.

31. Rodríguez-Tudela JL, Barchiesi F, Bille J, Chryssanthou E, Cuenca-Estrella M, Denning D, et al. Method for the determination of minimum inhibitory concentration (MIC) by broth dilution of fermentative yeasts. Clin Microbiol Infect 2003;9:i-viii.

32. Ahmad F, Tabassum N. Preliminary phytochemical, acute oral toxicity and antihepatotoxic study of roots of Paeonia officinalis Linn. Asian Pac J Trop Biomed 2013;3:64-8. 